Ivan Lupić

Stanford University

ilupic@stanford.edu

Irena Bratičević

University of Zagreb

irena.braticevic@ffzg.hr
Data przesłania tekstu do redakcji: 05.10.2016

Data przyjęcia tekstu do druku: 19.02.2017

\title{
Literary Collectors as Literary Scribes: The Case of Đuro Ferić (1739-1820)
}

\begin{abstract}
Lupić Ivan, Bratičević Irena, Literary Collectors as Literary Scribes: The Case of Đuro Ferić (1739-1820). "Poznańskie Studia Slawistyczne" 14. Poznań 2018. Publishing House of the Poznań Society for the Advancement of the Arts and Sciences, pp. 129-147. ISSN 2084-3011.

The essay reconstructs the scribal collection of Ragusan literature compiled by Đuro Feric (1739-1820 ) and currently scattered across various libraries. It argues that the focus on individual scribes is the best way of understanding Ragusan manuscript culture and of identifying relationships among different manuscript witnesses. Once scribal collections are reconstructed, it is possible to determine to what extent scribes understood their job as involving specific editorial decisions rather than just mechanical copying of the text in front of them. The approach is recommended not just to scholars interested in manuscript culture but to those interested in the larger questions of literary history as well.
\end{abstract}

KeYwords: Đuro Ferić (1739-1820); Ragusan literature; manuscript studies; scribal culture; history of literature; history of collecting

For centuries, and well into the age of print, Ragusan literary culture was a culture of predominantly manuscript composition, publication, and circulation. Although there had been attempts to bring the art of printing with movable type to the Republic of Ragusa (1358-1808) as early as the late fifteenth century, it was not until the second half of the eighteenth century that the authorities allowed a printer to set up a business in the city ${ }^{1}$. The establishment of a permanent printing shop in the city did not mean, however, that the Ragusan literary tradition immediately found its way into

${ }^{1}$ Rešetar, 1923, 397-398; Muljačić, 1956; Čučić, 2005. 
print. On the contrary, large-scale publishing projects focused on Ragusan literary classics consistently failed. It is only with the consolidated efforts of the Yugoslav (now Croatian) Academy of Sciences and Arts in the second half of the nineteenth century that a major editorial project endeavored to trace the textual transmission of individual literary works and to make available in print, and within the framework of a national literature, the literary achievements of the Ragusan Republic ${ }^{2}$. This project has, unfortunately, to this day remained unfinished. Moreover, it is becoming increasingly clear that even the Academy editions regularly fail to make sense of the complicated textual problems caused by centuries of manuscript transmission and by the disjointed and dispersed nature of the surviving evidence. While some Ragusan authors did publish their vernacular works outside of Ragusa, chiefly in Italian cities, most either relied on manuscript publication or were forced into it by the circulation of unauthorized copies of their works.

The study of Ragusan literary manuscripts, like the study of literary manuscripts more generally, has always been prompted by an interest in individual literary texts rather than the work of individual scribes. More often than not, this has resulted in a fragmented and frequently erroneous understanding of the manuscript tradition: one editor's focus on a particular author exposes him to the work of various scribes, but the scribes remain unidentified and their habits unknown. As a result, manuscripts are misdated, relationships among manuscripts are poorly understood, scribes are blamed for everything that is wrong with the text, and the history of a text's transmission adds up to a nice muddle. But once we approach the manuscript tradition from the perspective of scribal activity, we can reconstruct individual collections of scribal texts, now for the most part scattered across different libraries, we can identify networks of relationships among scribes, and we can determine to what extent scribes understood their job as involving specific editorial decisions rather than just mechanical copying of the text in front of them. There cannot be good editions of Ragusan literary classics without a good overall understanding of Ragusan scribal culture, nor can there be good histories of Ragusan literature if the role of Ragusan scribes is ignored ${ }^{3}$.

${ }^{2}$ On the Academy editions, see Lupić, 2010; on the earlier, unsuccessful attempts, see Lupić, 2012, 912-914; 2014, 49-51.

${ }^{3}$ For a more comprehensive discussion of this question with reference to specific editorial projects, see Lupić, 2012; Bratičević, Lupić, 2013; Lupić, 2014; Bratičević, 2015. 
This essay takes as its theme the work of a single Ragusan scribe, Đuro Ferić (Georgius Ferrich; Giorgio Ferrich; 1739-1820), who also happened to be a distinguished literary author in both Latin and the Croatian vernacular ${ }^{4}$. Like other Ragusan authors, he was also fluent in Italian, the language he used to maintain literary friendships outside of Ragusa. Ferić's longer Latin works include his Periegesis orae Rhacusanae, a poetic description of the Ragusan coastland and the nearby islands in three books, as well as De laudibus Epidauri, another work focused on local history and customs. He was a prolific author of epigrams: in addition to five books of Latin epigrams on various topics, he wrote epigrams in praise of Ragusan authors, a series of mostly satirical epigrams about his contemporaries, and more than a thousand epigrams based on Erasmus' Apophthegmata. He wrote poetic epistles in Latin hexameters addressed to various learned correspondents abroad, often informing them about Slavic folk poetry. The oral literature of the South Slavs was his life-long interest, evident especially in his amplified metrical versions of Croatian proverbs and their translations into Latin. Finally, he translated the fables of Phaedrus into Croatian and composed, in both Latin and Croatian, a versified biography of Aesop ${ }^{5}$.

Ferić was an amateur scribe. Whenever he was unable to obtain an older manuscript or to get hold of a printed edition of a Ragusan text, he was compelled to copy it for himself on the basis of exemplars borrowed from others. In this he had distinguished predecessors, who similarly formed for themselves their own versions of their city's literary past. To stay in the eighteenth century, the great age of antiquarianism and the cradle of Ragusan literary studies, we can name a number of important figures, among them Ivo Natalić Aletin (1670-1743), Đuro Matijašević (1675-1728), Lovro Cekinić (1692-1752), Franatica Sorkočević (1706-1771), Ivan Marija Matijašević (1714-1791), Miho Džonov Rastić (1716-1768), Ivan Ksaver Altesti (1727-1816), Ivan Salatić Mlađi (1759-1829). We could also mention many others, including those whose identities still

Even the most recent history of Ragusan literature has nothing to say about the role of Ragusan scribes; see Bojović, 2014.

${ }^{4}$ For an overview of Ferić's career, see Pantić, 1979 and Puratić, 1982.

${ }^{5}$ Our list is still just a selection. Ferić's works remain largely unedited. A significant exception is the edition of Ferić's translations of Slavic folk poetry, Slavica poematia latine reddita, for which see Wirtz, 1997. 
remain unknown but whose handwriting can serve as a guide in the process of reconstructing their collections and understanding their collecting interests and scribal habits. Because they are unsigned, Ferić's own manuscript copies of Ragusan literary texts have for the most part remained unidentified even though scholars have known for some time that Ferić must have been a literary scribe and that his collection was of considerable interest ${ }^{6}$.

There are three manuscript lists - preserved today in Prague, Zagreb, and Dubrovnik - that describe the contents of twenty manuscript volumes of Ragusan literature copied by Ferić ${ }^{7}$. These lists served as the primary guide in our attempt to reconstruct Ferić's manuscript collection by conducting research in various European libraries. In some cases, our task was made easier by the existing identifications of Ferić's hand; in other cases, it was made harder for the same reason. Some of the existing ascriptions, especially the more recent ones, are actually erroneous, which meant that we could not take anything on trust, even when offered by scholars who have written extensively on Ragusan literature ${ }^{8}$. In every case, we verified Ferić's handwriting by independently comparing it against his undisputed autographs, particularly his letters ${ }^{9}$. The results of our research, which has taken several years, are here published for the first time ${ }^{10}$. While we have not been able to locate all twenty volumes, we have located the majority. More importantly, we have found that Ferić's scribal efforts extended far

${ }^{6}$ Pantić, 1957, 123; 1965, 421; 1979, 115; Puratić, 1982, 12, 116, 120 (note 26).

${ }^{7}$ HAZU MS I. d. 110; SK MS T 4149 (a faithful copy of the former); ZKD MS 785. The original list was composed either during Ferić's lifetime or shortly after his death, as one of the three surviving copies (ZKD MS 785) is in the hand of Inocent Čulić (1782-1852). The abbreviations used in referring to specific libraries and manuscript repositories are as follows: AMB = Arhiv Male braće, Dubrovnik; Bizzaro = Zbirka Bizzaro, Zavod za povijesne znanosti HAZU, Dubrovnik; DAD = Državni arhiv, Dubrovnik; DSD = Dominikanski samostan, Dubrovnik; NSK = Nacionalna i sveučilišna knjižnica, Zagreb; ÖNB = Österreichische Nationalbibliothek, Vienna; SK = Slovanská knihovna, Prague; ZKD = Znanstvena knjižnica, Dubrovnik.

${ }^{8}$ See, for example, Mihanović-Salopek, Lupis, 2009, 83; Tatarin, 2010, 91. Both confuse Ferić with Miho Džonov Rastić. On the pernicious influence of similar confusions, see Lupić, 2012, 929-931.

${ }^{9}$ See Ferić's letters addressed to Ivan Bizzaro (DAD, RO-158, Obitelj Bizzaro, AB2) as well as his letters addressed to Iacopo Coleti (Biblioteca del Civico Museo Correr, Venice, Fondo Cicogna, MS 3201).

${ }^{10}$ See Lupić, 2012, 928, where the significance of Ferić's collection is recognized and the current article announced. 
beyond these twenty volumes: he copied other vernacular Ragusan texts and, as we would expect, texts that were written by Ragusan authors in Latin. We proceed by first giving an account of our findings regarding the list of twenty volumes and then turning to texts that are not listed there but that Ferić nonetheless copied.

Based on the three surviving lists of Ferić's manuscript collection of Ragusan literature, all of which differ only in the amount of detail they record, we have compiled a summary list that provides information on the authors and the works included in individual volumes as well as on where the volumes we have identified are to be found today (see Appendix I). On the spines of some of the manuscript volumes there are still labels with numbers that correspond to the numbering found in the lists, which further confirms the accuracy of our ascriptions. We do not have enough space here to provide detailed descriptions of each volume, but this is something we hope to do once we develop our digital database of Ragusan manuscripts ${ }^{11}$. Instead, given the confusion that characterizes the study of Ragusan manuscripts, our commentary is meant to be corrective in nature. On the one hand, it is meant to draw attention to previously unknown or, when scholarly editions exist, unused manuscripts. On the other hand, we point out instances when some of these manuscripts were used, even if their scribe often remained unidentified, because the current shelf-marks are not always the shelf-marks under which the manuscripts were kept when they were consulted in the nineteenth and twentieth centuries. It will be seen from our list that six out of twenty volumes are still missing, which does not necessarily mean that they have perished. In many cases, there are no published catalogs, and when catalogs are available, they are not always reliable. For example, the only published census of Ragusan manuscripts held in the library of the Dominican Monastery in Dubrovnik does not mention the volume we have found there (Vojnović, 1896, 1-45). Other library collections can be expected to produce similar surprises.

The first volume in Ferić's collection (HAZU MS VIII. 43) contains the text of Sunčanica, a seventeenth-century play that was first printed in 1840 in an edition that erroneously ascribed it to Ivan Šiškov Gundulić

${ }^{11}$ An initial phase of this project is being funded by the Roberta Bowman Denning Fund for Humanities and Technologies at Stanford University. 
(1678-1721), whereas the actual author seems to have been his father, Šiško Ivanov Gundulić (1633-1682) (Gundulić, 1840). Although Ferić's copy lacks the original title leaf, we can assume that it contained the same erroneous attribution because Ivan Šiškov is the author found in the lists of Ferić's manuscripts we have mentioned. While common in the manuscripts dating from the second half of the eighteenth century and later, the error is a surprising one given that it is not found in the surviving seventeenthcentury manuscripts, where Šško is named as the author (such as ZKD MS 13 from 1698, ZKD MS 166 from 1673/1679), or indeed in the manuscripts that were copied in the course of the eighteenth century (AMB MS 502, copied by Miho Džonov Rastić; AMB MS 270, copied by Ivan Marija Matijašević; NSK MS 3119, copied by Franatica Sorkočević, who was Šiško's grandson). Even when he writes the Latin epigrams in praise of Ragusan authors, Ferić mentions Ivan Šiškov Gundulić as the author of Sunčanica.

The twentieth-century editor of Sunčanica was unable to identify Ferić as the scribe of HAZU MS VIII. $43^{12}$. Nor was he able to identify the scribe who cut out Ferić's original title leaf and added, instead, four new leaves on which he provided a more elaborate title, a dedication to a Ragusan noblewoman dated 1840, and the list of dramatis personae. This later scribe was Marko Marinović (1791-1871), who seems to have been directly involved in the first print publication of Sunčanica from 1840. While the dedication in HAZU MS VIII. 43 is similar to what was eventually printed in 1840, there are significant differences between the two texts ${ }^{13}$. In the Slavonic Library in Prague, however, we have located another copy of Sunčanica written entirely in the hand of Marko Marinović (SK MS $\mathrm{T}$ 4199). It is the Prague manuscript that directly served as the basis for the 1840 edition, as can be seen from the marks left in it by the official censor, who crossed out several potentially offensive stanzas and recorded that he finished his task on July 29, $1839^{14}$.

${ }^{12}$ Hamm, 1962, 36. Hamm simply says that this is a nineteenth-century manuscript, probably led by the dedication that we discuss below and that was added later. It is of course perfectly possible, and we think likely, that Ferić copied Sunčanica in the eighteenth century.

${ }^{13}$ The differences are noted by Hamm, 1962, 6-7.

${ }^{14}$ The manuscript is not mentioned by Hamm. Interestingly, another manuscript held in Prague and written in Marinović's hand preserves marks of official censorship (SK MS $\mathrm{T}$ 4110). In it, the censor crossed out several passages, including the note explaining how 
The second volume in Ferić's collection (Bizzaro MS D. a. 31) contains the poetry of Dominko Zlatarić (c. 1558-1613), Šimun Zlatarić (c. 1593-1620), Maroje Mažibradić (between 1519 and 1525-1591), and Horacije Mažibradić (1565-1641). It consists of over four hundred pages. The manuscript has not been used in the existing scholarly editions of these poets, but it will prove useful in future editions as its text is occasionally better or more complete than what is found in other manuscripts ${ }^{15}$. While Ferić's second volume thus still awaits serious scholarly consideration, his third volume (AMB MS 133), containing religious drama by various Ragusan authors and an anonymous Nativity poem, served several editors in their work on individual plays (Daničić, 1872, V-IX; Budmani, 1886, XV; Rešetar, 1930, XXXII) ${ }^{16}$. None of them identified Ferić as the scribe. This is especially interesting because one of the editors in question was Milan Rešetar (1860-1942), who elsewhere showed familiarity with Ferić's hand. Rešetar both owned and used Ferić's fourth volume (SK MS T 4121), containing the poetry of Nikola Nalješković (c. 1500-1587) and others, and was eventually able to determine that Ferić was the scribe ${ }^{17}$. As late as 1930, however, we find Rešetar using two manuscripts written by Ferić - his volumes three and four - in one and the same edition without being able to tell that they were written by the same scribe (Rešetar, 1930, VI, XXXII).

Ferić's fifth volume (Bizzaro MS D. a. 36) brings together sixteenthcentury Ragusan tragedies. Here, we are helped by the early nineteenthcentury owner of the volume, Baldovin Bizzaro (1823-1848), who on the front pastedown correctly notes: „Manoscritto di mano del Ch. M. ${ }^{\mathrm{r}}$ Giorgio Ferrich / Poeta e letterato esimio". Unfortunately, even the most recent edition of these plays does not take into account this manuscript (Novak, $2006)^{18}$. Earlier editors, as a rule working in the nineteenth century, would

Pasiphaë managed to copulate with the bull. The volume contains the translations of Ovid's Heroides by Josip and Jakov Betondić.

${ }^{15}$ Compare, for instance, the text printed in Žepić, 1880, 124 with what is found in Bizzaro MS D. a. 31, 260.

${ }^{16}$ They all cite the manuscript by its old shelf-marks: 193 (31).

${ }^{17}$ Lupić, 2012, 925-927, where the history of this manuscript is reconstructed. Cf. Fališevac et al., 2015, 295, where the reconstruction of the history of this manuscript is overlooked.

${ }^{18}$ On the manuscripts of Držić's Hecuba, see Bratičević, Lupić, 2013, 106-107; Lupić, $2014,47$. 
have found it difficult to gain access to the Bizzaro manuscript collection since it was at that time in private hands ${ }^{19}$. Ferić's sixth volume (NSK MS 3186) contains Croatian translations of Ovid's Heroides, some of which still await print publication. Among these, interestingly, is Ferić's own translation of Sappho to Phaon, which also contains his occasional corrections. These were written in darker ink and, probably, at a later date. Despite the telling presence of the corrections, scholars who consulted the manuscript failed to identify its scribe ${ }^{20}$.

While the whereabouts of the seventh volume from Ferić's collection, containing the poetry of Ignjat Đurđević (1675-1737) and Petar Kanavelić (1637-1719), are still unknown, volume eight unexpectedly came to light in the summer of 2016, when the authors were granted access to the library of the Dominican monastery in Dubrovnik (DSD MS 34-VII-14). It contains the love poems and the epistles of the sixteenth-century Ragusan poet Nikola Nalješković. When in 2012 one of the authors of this article wrote about the manuscript tradition of Nalješković's works, he drew attention to the importance of Ferić's scribal activity in connection with Nalješković and pointed out that this volume must have at some point existed (Lupić, 2012, 928-929). He is now happy to report that the volume in question still exists, that it is in excellent condition, and that it amounts to over 200 leaves. The future editor of Nalješković will now be able to take this manuscript into account together with Ferić's volume eleven (HAZU MS I. a. 32), which contains Nalješković's plays and religious poetry, as well as his volume four (SK MS T 4121, see above), containing a handful of Nalješković's poetic epistles ${ }^{21}$.

Let us briefly consider the remaining volumes. Ferić's ninth volume (AMB MS 122) - which contains works by various authors, most of them from the sixteenth century - has been repeatedly used by editors, who, clueless about its scribe, variously dated it from the seventeenth to the end

\footnotetext{
${ }^{19}$ See Daničić, 1872; Žepić, 1878; 1880; Budmani, 1899. On the history of the Bizzaro collection, see Pantić, 1962, 558.

${ }^{20}$ Golik, 1901; Beritić, 1960. While Jurić, 1991, 79 similarly does not recognize the scribe, he also claims, erroneously, that the corrections are in a different hand.

${ }^{21}$ The most recent scholarly edition of Nalješković (Kapetanović, 2005) offers a very incomplete and frequently incorrect account of the manuscript transmission of his works, as shown by Lupić, 2010; 2012.
} 
of the eighteenth century ${ }^{22}$. His twelfth volume (AMB MS 2119), containing Ivan Gundulić's play Arijadna, is an example of a manuscript copy of a printed work, possibly mediated by other manuscripts before it reached Ferić. Arijadna was printed in Ancona in 1633, but there are probably more manuscript copies of it surviving than exemplars of the printed edition. Ferić's thirteenth volume (HAZU MS IV. a. 10), again previously not identified as his, has been used for an edition of Sofronija, a play by Vice Pucić Soltanović (c. 1620-1666) inspired by an episode in Tasso's Gerusalemme liberata (see Potthoff, 1975). Ferić's fourteenth volume (SK MS T 338) similarly features a seventeenth-century play, the tragedy Didone by Jaketa Palmotić Dionorić (1623-1680), but this manuscript is not even mentioned in the recent edition of the play ${ }^{23}$. His fifteenth volume (ÖNB MS Ser. n. 4471) is again a seventeenth-century play, this time about the encounter between Aeneas and Anchises in the underworld, written by Junije Palmotić (1607-1657). The only edition of this play was prepared in 1883 on the basis of a single manuscript dating from earlier in the nineteenth century (Pavić, 1883). Other manuscripts survive, going back to the seventeenth century, and they will need to be taken into account alongside the Ferić volume when a new scholarly edition of Palmotić's plays is undertaken ${ }^{24}$. The same applies to Ferić's volume sixteen (HAZU MS I. a. 37), containing Muka Isukrstova by Petar Kanavelić, a seventeenth-century religious drama that has recently been edited on the basis of a manuscript wrongly attributed to Ferić (Mihanović-Salopek, Lupis, 2009) $)^{25}$.

The six volumes we have not been able to locate so far are volumes seven, ten, and seventeen through twenty. But while searching for these volumes, we have come across many manuscripts of Ragusan literature copied by Feric that do not appear in the documents describing the contents of the twenty volumes. We provide a list of these new ascriptions in Appendix II, grouping them under the name of the library in which the manuscripts

${ }^{22}$ See more on the dating in Lupić, 2012, 928, note 80.

${ }^{23}$ See Mihanović-Salopek, Lupis, 2010. The editors fail to mention yet another Prague manuscript of Didone, SK MS T 396, copied by Miho Džonov Rastić in 1749.

${ }^{24}$ The manuscript is not mentioned in Potthoff, 1973, 48.

${ }^{25}$ For the correct attribution, see Lupić, 2012, 930-931. 
are currently held ${ }^{26}$. It will be seen that what is found outside of the twenty volumes amounts to almost as much text as what is found inside the twenty volumes. As we would expect, there are no duplicates. Ferić is clearly copying texts for his own use. In one case, however, he acquires a defective older manuscript (ZKD MS 921), for which he then supplies the missing bits, but he also copies the entire work in a separate manuscript (NSK MS 3129). It is hardly a surprise that the work in question is Ivan Gundulić's Osman, the most celebrated Ragusan literary classic ${ }^{27}$.

We hope that the findings presented in the two lists below will benefit from future research. We give them here for two reasons. First, we want other scholars to build on our work in their own investigation of Ragusan manuscript culture and of scribal culture more generally. Second, we want to show how much information about Ragusan manuscripts can be recovered despite the frequent disarray in the archives and despite the systematic neglect they have suffered. Our focus on an individual scribe is meant to provide a model not just for approaching Ragusan manuscript culture, but also for approaching the history of Ragusan literature more generally. We need better editions of almost all the texts of this literary tradition, but we also need to learn much more about how these texts were used, who read them, and whether the fact that many of them were never printed necessarily means that they did not circulate widely. Gundulić's Osman, the most frequently copied work of old Ragusan literature, continues to occupy the central place in the Croatian literary canon. But Gundulić today shares that place with Marin Držić, whose most celebrated comedy survives in a single sixteenth-century manuscript and is not copied again, if the surviving evidence is anything to go by, until it reaches print in the middle of the nineteenth century. Surely, this must be a question that is of interest not just to manuscripts scholars but to literary historians as well ${ }^{28}$.

\footnotetext{
${ }^{26}$ Among these manuscripts is AMB 446, which Wirtz was unable to use in her edition of Slavica poematia latine reddita, reporting that it had been lost $(1997,53)$. The manuscript survives, and it shows that Ferić sometimes included in the same volume folk poetry and works by Ragusan authors.

${ }^{27}$ NSK MS 3129 was later acquired by Marko Marinović, but obviously in a damaged state. So Marinović does for this Osman what Ferić did for the one he had acquired.

${ }^{28}$ The authors would like to thank Misha Teramura for his comments on an earlier version of this essay.
} 


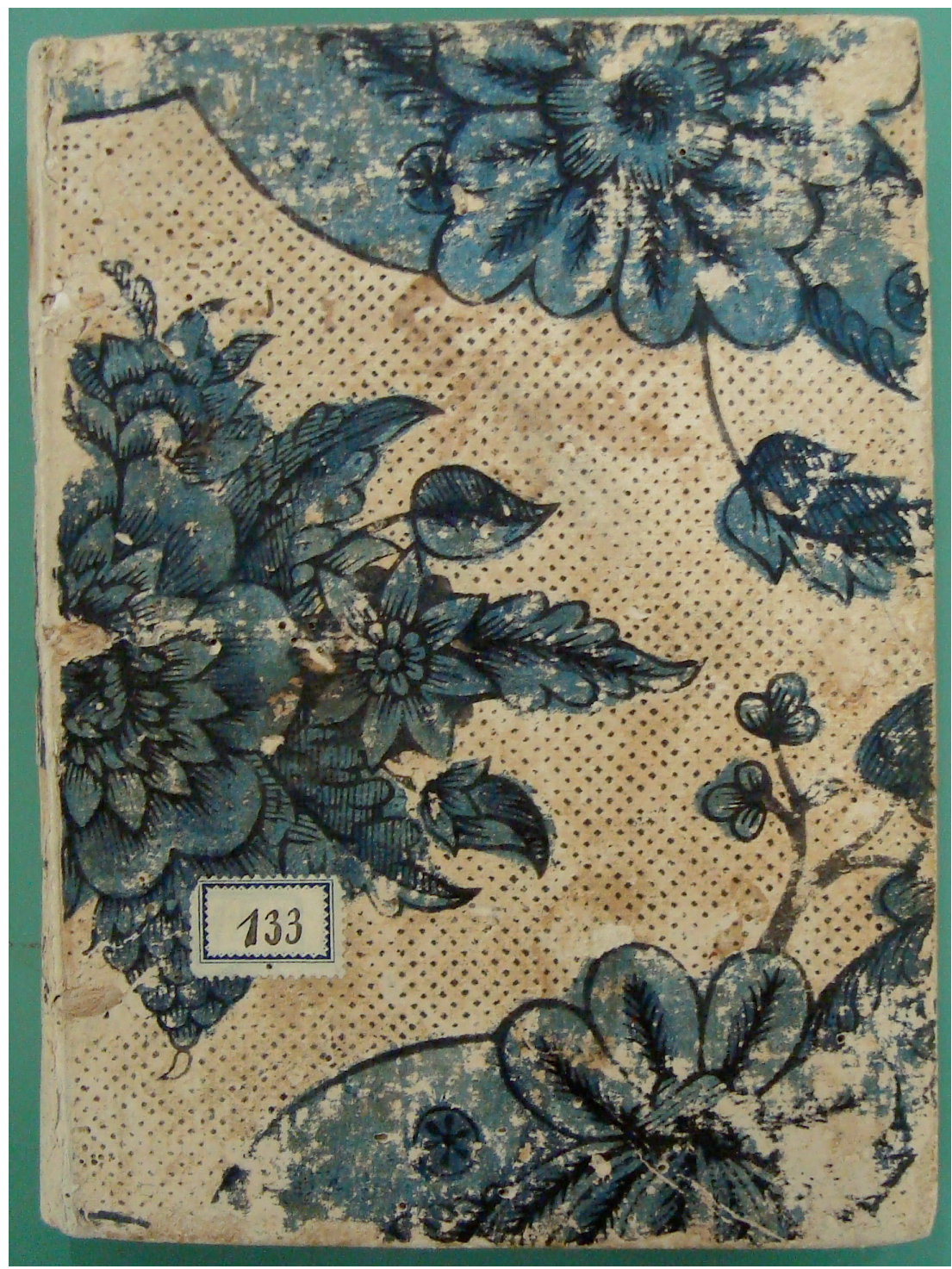

Figure 1. An example of the original binding of one of the twenty manuscript volumes from Ferić's collection (AMB MS 133). 


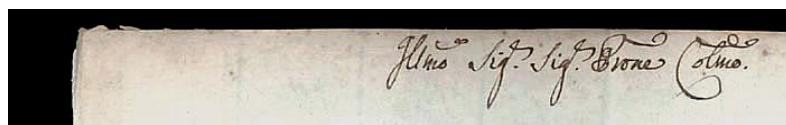

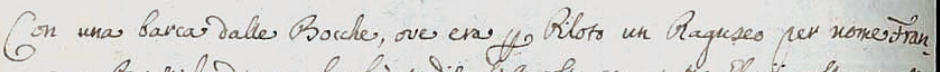

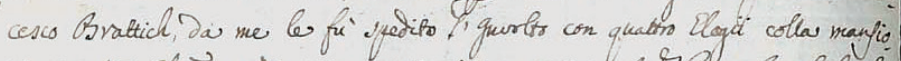

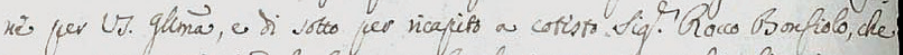

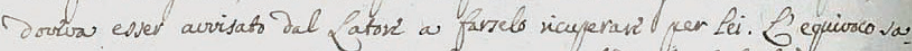

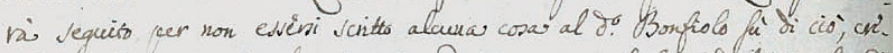

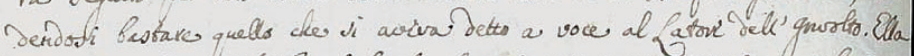

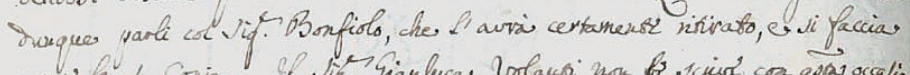

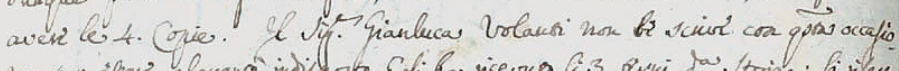

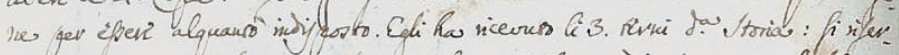

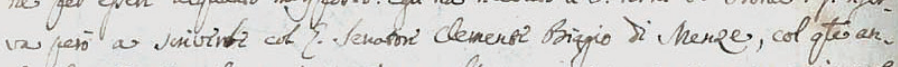

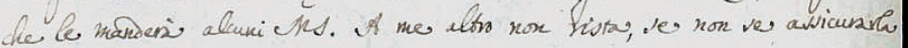

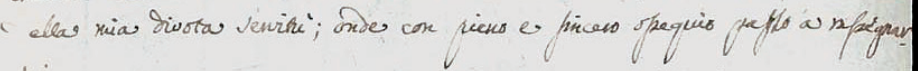
Jni

$$
\text { Raguva ki } 13 \text { kagis igg4. Di V. qutha }
$$

Figure 2. Đuro Ferić's letter to Iacopo Coleti, dated May 13, 1794 (Biblioteca del Civico Museo Correr, Fondo Cicogna, MS 3201). 


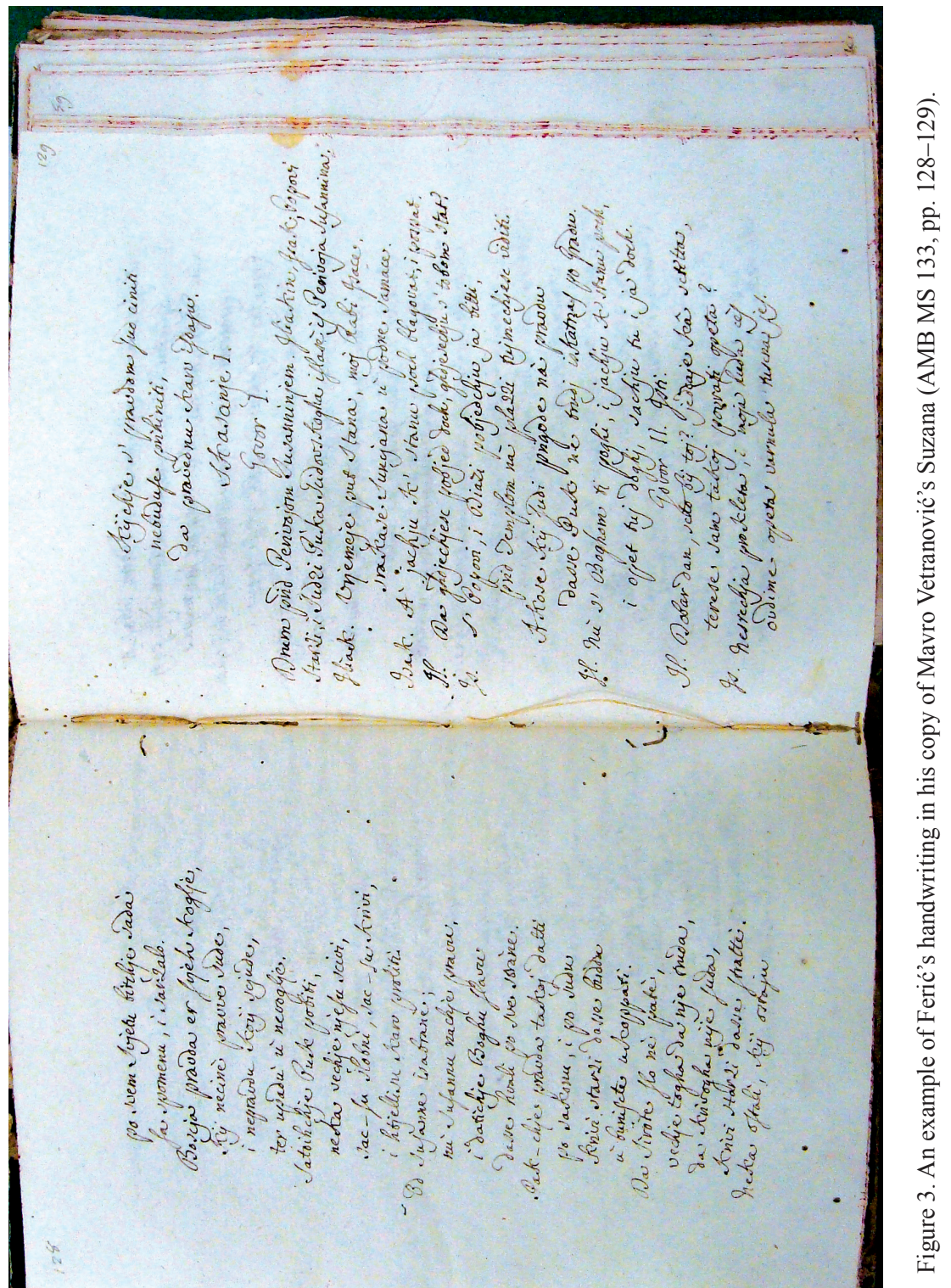




\section{APPENDIX I}

\section{Đuro Ferić's Twenty-Volume Scribal Collection of Ragusan Literature}

Vol. I (HAZU MS VIII. 43)

Šiško Gundulić (1633-1682), Sunčanica

Vol. II (Bizzaro MS D. a. 31)

Dominko Zlatarić (c. 1558-1613), Pjesni razlike; Šimun Zlatarić (c. 1593-1620), Libro prvo Pritvora Ovidiovijeh, Knjiga Leandrova, Pjesan Davidova; Horacije Mažibradić (1565-1641), Pjesni ljuvene; Maroje Mažibradić (between 1519 and 1525-1591), Pjesni

Vol. III (AMB MS 133)

Mavro Vetranović (1482-1576), Posvetilište Abramovo, Suzana čista, Porođenje Gospodinovo, Uskrsnuće Jezusovo; Petar Kanavelić (1637-1719), Život Tobije; Antun Gleđević (1656/1657-1728), Porođenje Gospodinovo; Anon., Pjesan vrhu porođenja Gospodinova

Vol. IV (SK MS T 4121)

Poetry by Nikola Nalješković (c. 1500-1587), Nikola Dimitrović (c. 1510-c. 1555), Marin Burešić (c. 1510-1572), Pasko Primović (c. 1565-1629), Petar Hektorović (1487-1572), Mavro Vetranović (1482-1576), Mikša Pelegrinović (c. 1500-1562), Sabo Bobaljević Mišetić (1529/1530-1585), and Šiško Menčetić (1457-1527)

Vol. V (Bizzaro MS D. a. 36)

Frano Lukarević Burina (c. 1541-1598), Atamante; Miho Bunić Babulinov (c. 1551-1617), Jokasta; Marin Držić (1508-1567), Hekuba; Dominko Zlatarić, Elektra

\section{Vol. VI (NSK MS 3186)}

Translations of Ovid's Heroides by Petar Bošković (1704-1727), Josip Betondić (1709-1764), Franatica Sorkočević (1706-1771), Ivan Ksaver Altesti (1727-1816), and Đuro Ferić

Vol. VII (currently unidentified)

Ignjat Đurđević (1675-1737), Pjesni razlike, Početak prvog pjevanja Eneide, Početak tragedije Judita; Petar Kanavelić, Pjesni razlike, Korunica imena Blažene Djevice Marije, Skup začinaka

Vol. VIII (DSD MS 34-XIII-14)

Nikola Nalješković, Pjesni ljuvene i poslanice 
Vol. IX (AMB MS 122)

Dominko Zlatarić, Ljubmir; Frano Lukarević Burina, Vjerni pastijer; Savko Gučetić Bendevišević (1531-1603), Dalida; Antun Sasin (c. 1518-?1595), Pjesni razlike; Mavro Vetranović, Istorija od Dijane, Drugo prikazanje, Orlača riđanka rečeno u Blatu ribarom

Vol. X (currently unidentified)

Ivan Šiškov Gundulić (1678-1721), Radmio; Junije Palmotić (1607-1657), Elena od Parida ugrabljena, Deidamija s Akilom

Vol. XI (HAZU MS I. a. 32)

Nikola Nalješković, Komedije, Pjesni bogoljubne, Pjesni od maskerate; Anon., translation of Parabosco's Favola d'Adone

Vol. XII (AMB MS 2119)

Ivan Gundulić (1589-1638), Arijadna

Vol. XIII (HAZU MS IV. a. 10)

Vice Pucić Soltanović (c. 1620-1666), Sofronija

Vol. XIV (SK MS T 338)

Jaketa Palmotić Dionorić (1623-1680), Didone

Vol. XV (ÖNB MS Ser. n. 4471)

Junije Palmotić, Enea slazi u pako za vidjeti Anhiza svoga oca

Vol. XVI (HAZU MS I. a. 37)

Petar Kanavelić, Muka Gospodina našega Isukrsta

Vol. XVII (currently unidentified)

Marin Držić, Tirena

Vol. XVIII (currently unidentified)

Jozo Betondić, Isukrst sudac

Vol. XIX (currently unidentified)

Junije Palmotić, Pavlimir, Lavinija, Natjecanje Ajača i Ulisa za oružje Akilovo, Razgovor među Colombom i družinom

Vol. XX (currently unidentified)

Ivan Gundulić, Prozerpina od Plutona ugrabljena, Pjesni razlike 


\section{APPENDIX II}

\section{Additional Ragusan Manuscripts Copied by Đuro Ferić}

\section{Arhiv Male braće, Dubrovnik}

MS 94

Ignjat Đurđević, Suze Marunkove

MS 446

Frano Bobaljević Kuko, Troja užežena; Džore Palmotić, Ači i Galatea, Ero vila; etc.

MS 886

Bernard Džamanjić, Ad clarissimum virum Thomam Watkinsium

Državni arhiv, Dubrovnik

Memoriae (21.2), MS 26

Ragusina Cessionis Navis

Memoriae (21.2), MS 93

Antonio Gigante, Vita di monsignore Ludovico Beccadelli

Memoriae (21.2), MS 137

Junije Palmotić, Ipsipile

\section{Znanstvena knjižnica, Dubrovnik}

MS 921

Ivan Gundulić, Osman (supplies the text missing from an older MS)

\section{Zbirka Baltazara Bogišića, Cavtat}

MS 12

Petar Kanavelić, Pastijer vjeran (supplies the text missing from an older MS)

\section{Arhiv Hrvatske akademije znanosti i umjetnosti, Zagreb}

MS I. a. 16

Junije Palmotić, Danica

MS I. b. 14

Junije Palmotić, Captislava (fragment)

MS I. b. 133

Jozo Betondić, various verse translations 
MS I. b. 134

Vladislav Menčetić, Radonja; Razgovor među Franom Škicom i Katarinom Prčom

MS I. c. 63

Poems by Michele Marullo Tarchaniota, Šiško Đurđević, Damjan Beneša, Ilija

Crijević, Karlo Pucić; Juraj Dragišić, De natura angelica (beginning)

MS I. d. 141

Didak Pir, Carmina

\section{Nacionalna i sveučilišna knjižnica, Zagreb}

MS 3129

Ivan Gundulić, Osman

MS 3238

Nikolica Bunić, Descriptio ditionis Ragusinae; Anon., Diario raguseo 1610-1637

MS 5196

Junije Palmotić, Alčina

\section{Narodna biblioteka Srbije (Legat Petra Kolendića), Beograd}

MS PKLR 34

Letters of Benedikt Rogačić; two Latin orations

MS PKLR 59

The Last Will and Testament of Jakov Lukarević

\section{Slovanská knihovna, Prague}

MS T 347

Julio Cesare Cordara, Sulla parucca di Ruggiero Boscovich; Rajmund Kunić, De ficta coma p. Rogerii Boschovichii; Elegiae; Alberto Fortis, Ad Ragusam epigramma; Anon., Epigramma

\section{Österreichische Nationalbibliothek, Vienna}

MS Ser. n. 4586

Luko Mihov Bunić, Aretuza u goru, Arion u rijeku; Ferić's Latin translation

MS Ser. n. 4597

Ivan Bunić Vučić, Mandalijena pokornica; poems in praise of Mandalijena; Ivan Dražić, Proslavjenje s. Dujma; Ivan Bunić Vučić, Vrhu s. Pelenice Jezusove; etc.

\section{British Library, London}

MS Add. 10032

Junije Palmotić, Captislava 


\section{References}

Beritić, N. (1960). Oko Betondićeva prijevoda Ovidijevih heroida. In: Beritićev zbornik. Ed. V. Cvitanović. Dubrovnik: Društvo prijatelja dubrovačke starine, pp. 197-215.

Bojović, Z. (2014). Istorija dubrovačke književnosti. Beograd: Srpska književna zadruga.

Bratičević, I. (2015). Via virtutis / Put vrline: Epigramatski opus Rajmunda Kunića. Zagreb: Ex libris.

Bratičević, I., Lupić, I. (2013). Držićeva „Hekuba” između izvedbe i knjige. “Colloquia Maruliana", vol. 22, pp. 77-116.

Budmani, P. (ed.) (1886). Djela Antuna Gleđevića. Stari pisci hrvatski, XV. Zagreb: Jugoslavenska akademija znanosti i umjetnosti.

Budmani, P. (ed.) (1899). Djela Dominka Zlatarića. Stari pisci hrvatski, XXI. Zagreb: Jugoslavenska akademija znanosti i umjetnosti.

Čučić, V. (2005). Prvi tiskari u Dubrovniku s popisom tiskane građe. "Vjesnik bibliotekara Hrvatske", vol. 48, pp. 108-158.

Daničić, Đ. (ed.) (1872). Pjesme Mavra Vetranića Čavčića. Vol. II. Stari pisci hrvatski, IV. Zagreb: Jugoslavenska akademija znanosti i umjetnosti.

Fališevac, D., Jovanović, N., Tatarin, M. (2015). Život i književno djelo Paska Primovića i njegov ep Od upućenja Riječi vječne i od poroda Djevičkoga. "Građa za povijest književnosti hrvatske", vol. 38, pp. 255-421.

Golik, J. (1901). O djelima Josipa Betondića Dubrovčanina. "Školski vjesnik”, vol. 8, pp. 48-60, 262-266, 404-415, 519-536, 753-773.

Gundulić, I.Š. (1840). Suncjaniza. Dubrovnik: Po Pet. Franu Martecchini.

Hamm, J. (1962). Gundulićeva Sunčanica. "Građa za povijest književnosti hrvatske", vol. 28, pp. 5-193.

Jurić, Š. (1991). Katalog rukopisa Nacionalne i sveučilišne biblioteke u Zagrebu. Knj. 1. Zagreb: NSK.

Kapetanović, A. (ed.) (2005). N. Nalješković, Književna djela. Zagreb: Matica hrvatska.

Lupić, I. (2010). Nove teorije i stare knjige. "Forum", vol. 49, pp. 1192-1238.

Lupić, I. (2012). Tekstološka načela, kritička izdanja i kroatistička znanstvena zajednica. "Forum", vol. 51, pp. 557-589; 895-958.

Lupić, I. (2014). Piligrinov otpor. In: Otpor. Subverzivne prakse u hrvatskome jezi$k u$, književnosti i kulturi. Eds. T. Pišković, T. Vuković. Zagreb: Filozofski fakultet Sveučilišta u Zagrebu, pp. 35-79.

Mihanović-Salopek, H., Lupis, V.B. (2009). Doprinos Petra Kanavelića hrvatskoj pasionskoj baštini. Split: Ogranak Matice hrvatske Split.

Mihanović-Salopek, H., Lupis, V.B. (2010). Željezni duh: prinos Jakete Palmotića Dionorića hrvatskoj književnoj baštini. Zagreb-Dubrovnik: Institut društvenih znanosti Ivo Pilar, Područni centar Dubrovnik.

Muljačić, Ž. (1956). O prvoj dubrovačkoj tiskari. "Anali Historijskog instituta JAZU u Dubrovniku", vol. 4/5, pp. 583-612. 
Novak, S.P. (ed.) (2006). Tragedije XVI. stoljeća. Stoljeća hrvatske književnosti. Zagreb: Matica hrvatska.

Pantić, M. (1957). Sebastijan Slade Dolči: dubrovački biograf XVIII veka. Beograd: Naučno delo.

Pantić, M. (1962). Rukopisi negdašnje biblioteke Bizaro u Historijskom institutu u Dubrovniku. "Anali Historijskog instituta JAZU u Dubrovniku", vol. 8/9, pp. 557-596 .

Pantić, M. (1965). Izrada biografije Đure Ferića i studije o njegovim delima na našem jeziku. "Ljetopis JAZU”, vol. 70, pp. 421-422.

Pantić, M. (1979). Ferić, Đuro. In: Leksikon pisaca Jugoslavije II. Ed. Ž. Boškov. Novi Sad: Matica srpska.

Pavić, A. (1883). Djela Gjona Gjora Palmotića, vol. II. Stari pisci hrvatski, XIII. Zagreb: Jugoslavenska akademija znanosti i umjetnosti.

Potthoff, W. (1973). Die Dramen des Junije Palmotić. Wiesbaden: F. Steiner.

Potthoff, W. (ed.) (1975). Dubrovniker Dramatiker des 17. Jahrhunderts, vol. 2. Giessen: W. Schmitz.

Puratić, Ž. (1982). Đorđe (Đuro) Ferić (život i djelo). Zagreb: Sveučilišna naklada Liber.

Rešetar, M. (1923). Iz kulturnoga života staroga Dubrovnika. "Jugoslavenska njiva", vol. 7.9, pp. 367-372; 7.10, pp. 396-403.

Rešetar, M. (ed.) (1930). Djela Marina Držića. Stari pisci hrvatski, VII. Zagreb: Jugoslavenska akademija znanosti i umjetnosti.

Tatarin, M. (2010). Rekonstrukcija drame Filide Antuna Sasina. "Građa za povijest književnosti hrvatske", vol. 37, pp. 79-128.

Vojnović, K. (1896). Prilozi k arhivalnijem pabircima dubrovačkijem. "Starine", vol. 28, pp. $1-96$.

Wirtz, G. (ed.) (1997). Đuro Ferić, Slavica poematia latine reddita: Eine frühe südslavische Volksliedsammlung. Köln-Weimar-Wien: Böhlau.

Žepić, S. (ed.) (1878). Djela Frana Lukarevića Burine. Stari pisci hrvatski, X. Zagreb: Jugoslavenska akademija znanosti i umjetnosti.

Žepić, S. (ed.) (1880). Pjesme Miha Bunića Babulinova, Maroja i Oracia Mažibradića, Marina Burešića. Stari pisci hrvatski, XI. Zagreb: Jugoslavenska akademija znanosti i umjetnosti. 